\title{
Experimental Research in Boost Driver with EDLCs
}

\author{
Hirokazu Matsumoto Member (Fukuoka University, matsumoto@fukuoka-u.ac.jp)
}

Keywords: EDLC, motor driver, boost circuit, reduction of input power peak, regenerative energy storage

The supply used in servo systems tends to have a high voltage in order to reduce loss and improve the response of motor drives. We propose a new boost motor driver that comprises electric double layer capacitors (EDLCs). The proposed driver has three advantages over conventional boost motor drivers. The first advantage is that the driver can easily attain the stable boost voltage. The second advantage is that the driver can reduce input power peaks. In a servo system, the input power peaks become greater than the rated power in order to accelerate the motor rapidly. This implies that the equipments that supply to servo systems must have sufficient power capacity to satisfy the power peaks. The proposed driver can suppress the increase of the power capacity of supply facilities. The third advantage is that the driver can store almost all of the regenerative energy. Conventional drivers have a braking resistor to suppress the increase in the DC link voltage. This causes a considerable reduction in the efficiency. The proposed driver is more efficient than conventional drivers.

Fig. 1 shows the structure of the proposed boost driver. $\mathrm{C}_{1}$ represents EDLCs and $\mathrm{C}_{2}$ and $\mathrm{C}_{3}$ represent electric capacitors. The EDLCs, which are charged by the charge circuit in advance, are connected in series to a supply and functions as a charge pump by boosting the DC link voltage. An EDLC has a large capacitance value and the ability to charge and discharge rapidly. These characteristics enable the driver to attain the stable boosted voltage. Moreover, the driver comprises a charge circuit to charge the EDLCs. This circuit enables the driver to store almost all of the regenerative energy and utilize it efficiently.

Fig. 2 shows the experimental results. In the experiments, six EDLC modules with a rated capacitance of $116 \mathrm{~F}$ and a rated voltage of $15 \mathrm{~V}$ connected in series are used. The other constants are $C_{2}=$ $0.94 \mathrm{mF}, C_{3}=0.22 \mathrm{mF}$ and $L=4.53 \mathrm{mH}$. The supply voltage is $60 \mathrm{~V}$ (DC); the EDLCs are charged at $60 \mathrm{~V}$ in order to boost $e_{3}$ to $120 \mathrm{~V}$. The motor is a permanent magnet synchronous motor (PMSM) with a rated power of $400 \mathrm{~W}$ and a rated speed of $3000 \mathrm{rpm}$. It is driven in an acceleration and deceleration pattern by $200 \%$ of the rated torque.

The result of the EDLCs voltage $e_{1}$ shows that its variation is very small. The results of speed; dq-axes current feedbacks $i_{d}, i_{q}$; and voltage $e_{3}$ suggest that the proposed driver can achieve the same drive performance as a conventional driver. The input power peak is about $600 \mathrm{~W}$, which is half the input power peak of a conventional driver. During deceleration, the driver goes into regenerative mode, thereby increasing voltage $e_{3}$. At $130 \mathrm{~V}$, the charge circuit works and then the current $i_{L}$ flows through the inductor L, thereby enabling the charge circuit to suppress an increase in the voltage. It also means that the excessive energy in electric capacitors is transferred to the EDLCs. In a conventional driver, a braking resistor is used to suppress the increase, thereby leading to the dissipation of $8.09 \mathrm{~J}$ of regenerative energy.

These experimental results show the effectiveness of the proposed boost driver that comprises EDLCs.

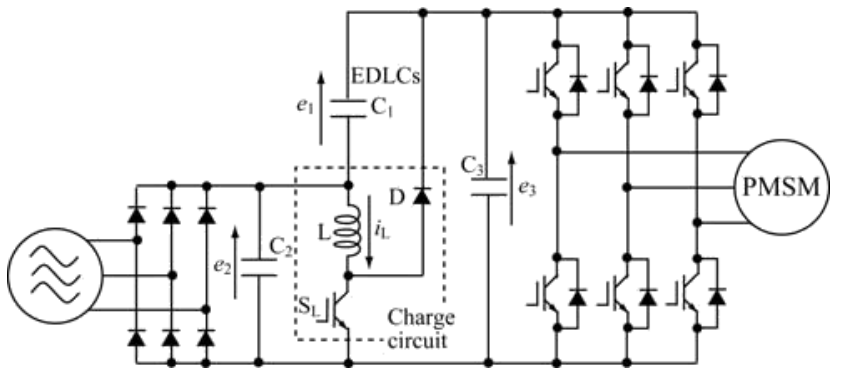

Fig. 1. Proposed boost driver
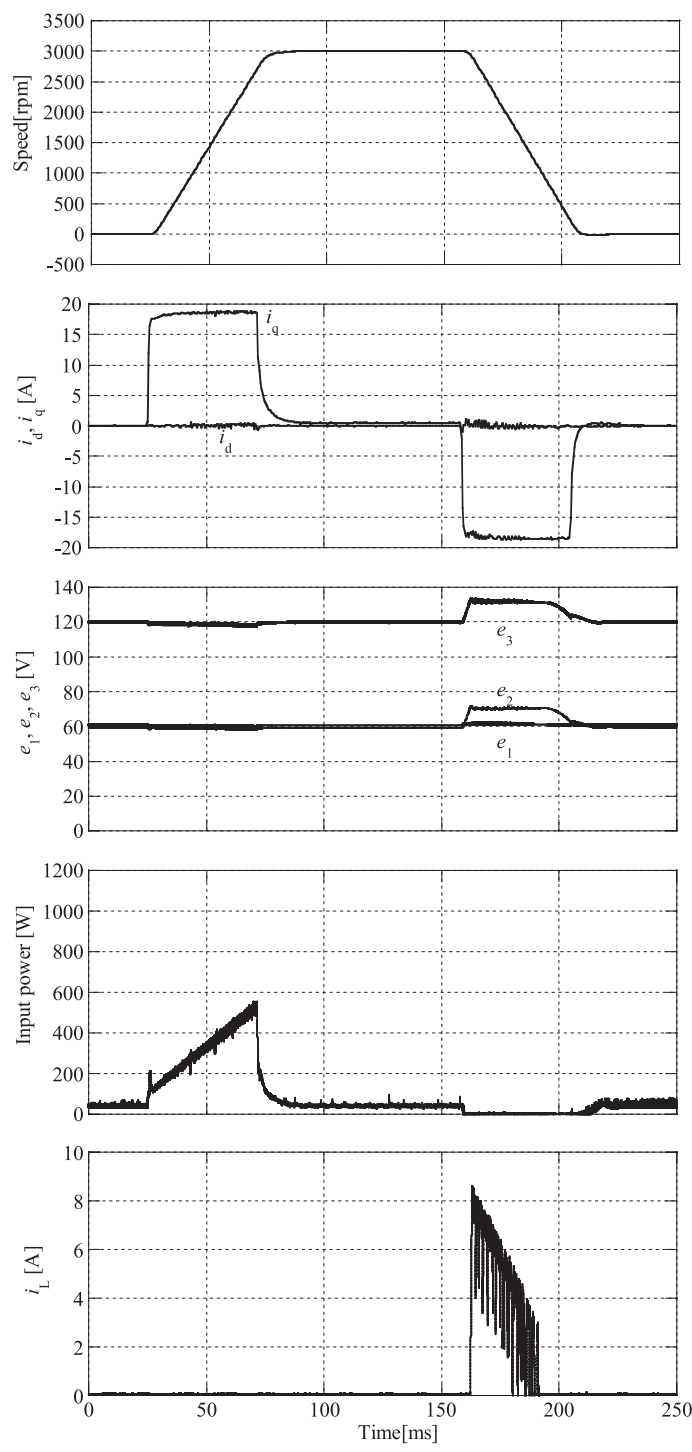

Fig. 2. Experimental results of the proposed boost driver 


\title{
電気二重層キャパシタを用いた昇圧形ドライバの 実験による性能検証
}

\author{
正 員 松本 洋和*
}

\section{Experimental Research in Boost Driver with EDLCs}

\author{
Hirokazu Matsumoto*, Member
}

\begin{abstract}
The supply used in servo systems tends to have a high voltage in order to reduce loss and improve the response of motor drives. We propose a new boost motor driver that comprises EDLCs. The proposed driver has a simple structure, wherein the EDLCs are connected in series to the supply, and comprises a charge circuit to charge the EDLCs. The proposed driver has three advantages over conventional boost drivers. The first advantage is that the driver can easily attain the stable boost voltage. The second advantage is that the driver can reduce input power peaks. In a servo system, the input power peaks become greater than the rated power in order to accelerate the motor rapidly. This implies that the equipments that supply power to servo systems must have sufficient power capacity to satisfy the power peaks. The proposed driver can suppress the increase of the power capacity of supply facilities. The third advantage is that the driver can store almost all of the regenerative energy. Conventional drivers have a braking resistor to suppress the increase in the DC link voltage. This causes a considerable reduction in the efficiency. The proposed driver is more efficient than conventional drivers. In this study, the experimental results confirmed the effectiveness of the proposed driver and showed that the drive performance of the proposed driver is the same as that of a conventional driver. Furthermore, it was confirmed that the results of the simulation of a model of the EDLC module, whose capacitance is dependent on the frequency, correspond well with the experimental results.
\end{abstract}

キーワード：電気二重層キャパシタ, モータドライバ, 昇圧回路, 入力電力ピーク低減, 回生エネルギー貯蔵

Keywords: EDLC, motor driver, boost circuit, reduction of input power peak, regenerative energy storage

\section{1. まえがき}

近年，産業用サーボシステムの使用電源は，システムの 高効率化及びモー夕駆動出力の高速応答化を目指し，高電 圧化される傾向にある。しかし, 既存の電源設備を高電圧 化することは，コスト・労力の面から現実的ではない。そ こでドライバ内部で電圧を昇圧することが考えられる。

筆者は, 昇圧形モータドライバとして電気二重層キャパ シタ（EDLC : Electric Double Layer Capacitor）を用いた 昇圧形ドライバを提案した (1)。このドライバは (i) 安定し た昇圧性能 (ii) 入力電力ピーク低減 (iii) 回生エネルギー貯 蔵・有効利用の 3 つの特長があることが, シミュレーショ ンにより確認されている。

サーボモータはタクトタイム短縮のため定格の数倍のト ルクにより加速が行われることが多い。この時必要な電力

\footnotetext{
* 福岡大学

干 814-0180 福岡市城南区七隈 8-19-1

Fukuoka University

8-19-1, Nanakuma, Jonan-ku, Fukuoka 814-0180
}

ピークは定格の数倍となる。提案ドライバはこのような急 峻な電力変動に対しても安定した昇圧が可能である。また この電力ピークは, サーボシステムに電力を供給する電源 設備の容量増加をもたらしている。損失を考えない場合, サーボシステムが使用する平均電力は, 定格を超えること はない。そのため電源設備はシステムの定格容量を満たし ていればよいはずである。しかし定格を大きく超える電力 ピークが存在するため, 電源設備はシステムの定格より大 きな容量に設定され, 余剩容量を持つことになる。一方, 提 案するドライバは入力電力ピークを低減できるため, 従来 ドライバに比べ電源設備の余剩容量を低減し, 電源設備に 対するコストの削減を図ることが可能である。

現在, 市販されている小から中容量のサーボドライバは 回生抵抗を備えている。これは過㮃な回生動作が行われた 際に，ドライバ内部の平滑コンデンサの電圧上昇を抑制す るためであるが, 一方でドライバの効率を大きく低下させ る原因となっている。本提案回路ではほぼ全ての回生エネ ルギーをEDLCへと貯蔵可能であるため有効利用が可能で ある。 
本論文は, 提案ドライバにおいてモータ加減速運転実験 を行い, 以上 3 つの特長に関して従来ドライバとの比較検 証を行いその有効性を確認する。また多段時定数回路を基 にモデル化したEDLC モデルを用いてシミュレーションを 行い, 実験結果との整合性を検証するとともにEDLC が持 つ周波数依存特性の影響を検証する。

\section{2. 提案ドライバの構成と EDLC 特性}

〈2・1〉提案ドライバの構成Ｆig. 1 は提案する昇圧形 ドライバの構成図である。コンデンサ $\mathrm{C}_{1}$ は EDLC, $\mathrm{C}_{2}$ と $\mathrm{C}_{3}$ は電解コンデンサである。EDLC は電源用平滑コンデ ンサ $\mathrm{C}_{2}$ に直列接続されており，EDLC を充電することに よりインバータ入力電圧 $e_{3}$ を充電電圧分昇圧する。EDLC は非常に大きな静電容量を持ち, また電解コンデンサのよ うに高速充放電が可能であるため近年注目を集めている ${ }^{(2)}$ 。 しかし 1 個あたりの定格電圧が $2 \mathrm{~V}$ 前後と低いことが高 電圧回路への適用の障害となっていた。本提案ドライバは EDLC を補助的に使用するため, 昇圧分の定格電圧を考慮 すればよい。なお本論文では定格 $15 \mathrm{~V}$, 定格静電容量 $116 \mathrm{~F}$ のEDLC モジュールを多段直列接続し使用した。

ところで本来電解コンデンサ $\mathrm{C}_{2}$ からインバータ回路に かけては浮遊インダクタンスを抑えるため電流路は最短に 設計される。しかし提案ドライバは直列接続された EDLC があるため, 浮遊インダクタンス值が大きくなる可能性が ある。この浮遊インダクタンスによる電圧サージを吸収す るため電解コンデンサ $\mathrm{C}_{3}$ が挿入されているが， $\mathrm{C}_{2}$ に比べ 小さな静電容量でよい。

昇圧の仕組みは, 電源に直列接続された EDLC がチャー ジポンプとして働くシンプルな構成である。そのため昇圧 チョッパ(3) (5) のように常時チョッピングを行う必要はなく, 昇圧電圧を一定に保つための電圧応答性が問題となること もない。またEDLCがモー夕駆動に必要な電力の一部を負 担するため入力電力ピークを低減可能である。低減後の入 力電力ピークは従来形ドライバと比べて以下の割合 $M$ に低 減される。

$$
M=\frac{e_{2}}{e_{1}+e_{2}}
$$

本ドライバの特徵は, チョークコイル $\mathrm{L}$, スイッチ $\mathrm{S}_{\mathrm{L}}$, ダイオード D からなる充電回路である。これにより昇圧の ための EDLC 初期充電を行うとともに回生エネルギーをほ ぼ全て EDLCへと充電可能である。同様の回路構成で昇圧 する回路が文献(6) で述べられているが，モー夕回生時に しか EDLC 充電を行えないため, 駆動開始時は昇圧回路と して機能できない。またEDLCを通過した回生電流は電解 コンデンサに流れ込むため, サーボドライバに適用した場 合, 電解コンデンサの電圧を抑えるため回生抵抗が必要に なる。

Fig. 2(a)に電源充電モード時の電流を示す。この時，回 路構成はバックブーストになっている。また Fig. 2(b) に回 生充電モード時の電流を示す。回生充電時には, 回生電流

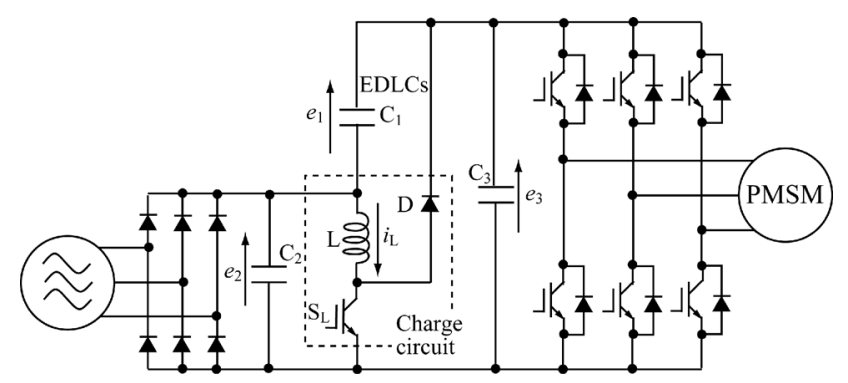

Fig. 1. Proposed boost driver.
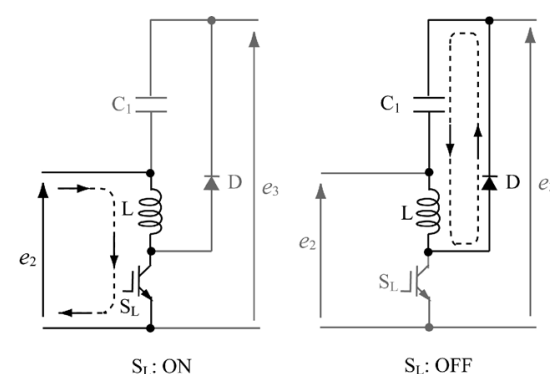

$\mathrm{S}_{\mathrm{L}}$ : OFF

(a) Supply charge mode
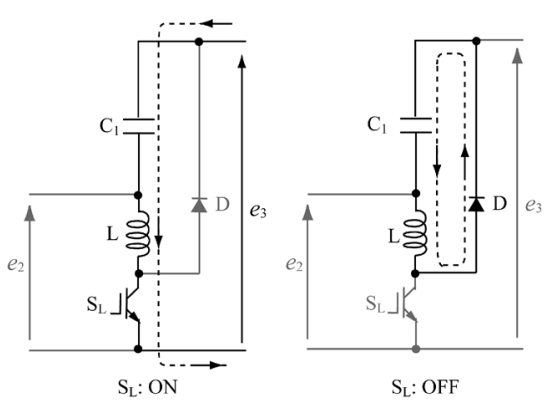

(b) Regenerative charge mode

Fig. 2. EDLC charge operation.

は EDLC と $\mathrm{C}_{2}$ を通過することにより充電する。 $\mathrm{C}_{2}$ は電解 コンデンサであるため電圧 $e_{2}$ は急激に上昇する。そこで充 電回路が働き, $\mathrm{C}_{2}$ の過剰エネルギーを EDLCへと送り電 圧上昇を抑制する。EDLC は静電容量が大きいため送られ たエネルギーをわずかな電圧変動のみで吸収可能である。 このとき $\mathrm{C}_{2}$ を通過する短時間平均電流は 0 とみなすこと ができる。これより回路構成は, バックコンバータとみな すことができる。この時インダクタ $\mathrm{L}$ の短時間平均電流 $I_{\mathrm{L}}$ は回生電力 $W$ とすると以下のように表わされる。

$$
I_{\mathrm{L}}=\frac{W}{e_{1}}
$$

但し回生電力は以下となる。

$$
W=k_{e} i_{q} \omega
$$

ここで $k_{e}, i_{q}, \omega$ はそれぞれモータの誘導起電圧定数, $\mathrm{q}$ 軸 電流，角速度である。

$\langle 2 \cdot 2\rangle$ EDLC の特性 本提案回路では入力電力ピー クを低減する目的から, 加速時にEDLCへの充電は行わな い。一方で, サーボシステムでは, 加速時に定格の数倍の 電力が要求される。この条件下で, EDLC は安定して電圧 


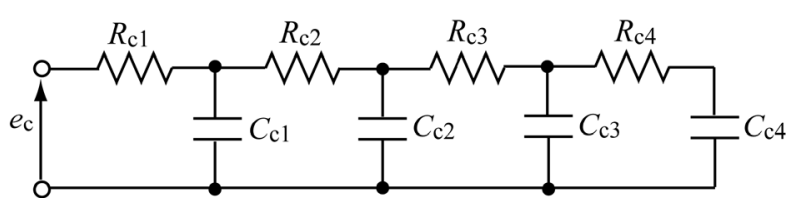

Fig. 3. EDLC module model.

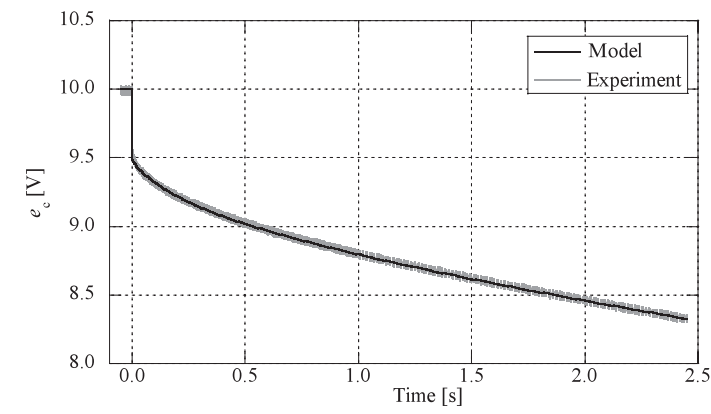

Fig. 4. Discharge characteristic in EDLC module.

Table 1. Constants of EDLC module model.

\begin{tabular}{|l|c||c|c|}
\hline$R_{\mathrm{c} 1}$ & $0.0171 \Omega$ & $C_{\mathrm{c} 1}$ & $7.00 \mathrm{~F}$ \\
\hline$R_{\mathrm{c} 2}$ & $0.00250 \Omega$ & $C_{\mathrm{c} 2}$ & $11.5 \mathrm{~F}$ \\
\hline$R_{\mathrm{c} 3}$ & $0.0130 \Omega$ & $C_{\mathrm{c} 3}$ & $39.5 \mathrm{~F}$ \\
\hline$R_{\mathrm{c} 4}$ & $0.0300 \Omega$ & $C_{\mathrm{c} 4}$ & $58.0 \mathrm{~F}$ \\
\hline
\end{tabular}

を保つことが要求される。そのためEDLC の静電容量特性 は無視できない要素である。

EDLC の静電容量は周波数に対して大きな依存性を持ち, 単純にCで表すことはできない(7)。EDLC のモデル化に関 しては様々な研究がなされているが(2)(8)(9), 本論文では Fig. 3 に示す多段時定数回路を用いてモデル化を行った。Fig. 4 に 定電流 30A で放電したときの EDLC モジュール電圧 $e_{c}$ を 示す。この結果を基にカーブフィッティングを行い, EDLC モデルの定数を求めた。なお，電圧が放電しきらない比較 的短時間の放電カーブを用いたのは, 時定数が短い領域で の特性をより正確に再現するためである。Table 1 に得られ たEDLCモデル定数を示す。また，得られたモデルによる 放電シミュレーション結果を Fig. 4 の濃実線で示す。

EDLC モデルのインピーダンスは以下のように表わさ れる。

$$
Z=\frac{\left(1+a_{2} \omega^{2}+a_{4} \omega^{4}\right)+j \omega\left(a_{1}+a_{3} \omega^{2}\right)}{\omega^{2}\left(b_{2}+b_{4} \omega^{2}\right)+j \omega\left(b_{1}+b_{3} \omega^{2}\right)}
$$

但し, $\mathrm{a}_{1}=5.26, \mathrm{a}_{2}=-3.31, \mathrm{a}_{3}=-3.39 \times 10^{-3}$, $\mathrm{a}_{4}=3.07 \times 10^{-3}, \mathrm{~b}_{1}=116, \mathrm{~b}_{2}=-126, \mathrm{~b}_{3}=$

$-18.3 \times 10^{-1}, b_{4}=1.80 \times 10^{-1}$

上式を見かけ上の内部抵抗 $R_{c}(\omega)$ と静電容量 $C_{c}(\omega)$ を用い て以下のように表わすことができる。

$$
Z=R_{c}(\omega)+\frac{1}{\mathrm{j} \omega C_{c}(\omega)} \cdots
$$

ここで,

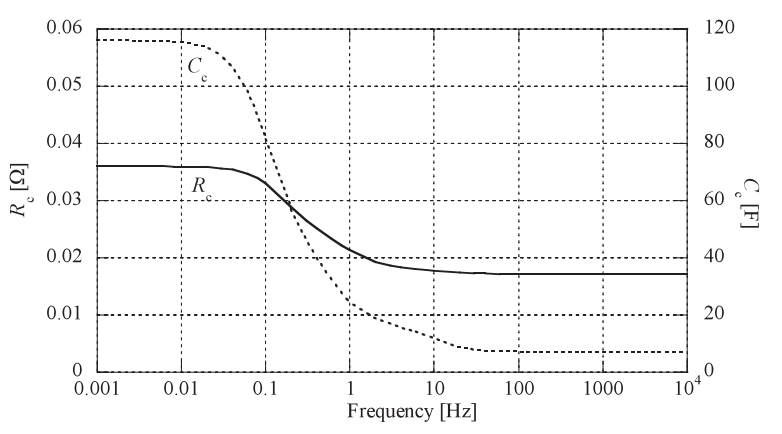

Fig. 5. $R_{c}(\omega)$ and $C_{c}(\omega)$.

$$
\begin{aligned}
& R_{c}(\omega)=\frac{\left(1+\mathrm{a}_{2} \omega^{2}+\mathrm{a}_{4} \omega^{4}\right)\left(\mathrm{b}_{2}+\mathrm{b}_{4} \omega^{2}\right)+\left(\mathrm{a}_{1}+\mathrm{a}_{3} \omega^{2}\right)\left(\mathrm{b}_{1}+\mathrm{b}_{3} \omega^{2}\right)}{\left(\mathrm{b}_{1}+\mathrm{b}_{3} \omega^{2}\right)^{2}+\omega^{2}\left(\mathrm{~b}_{2}+\mathrm{b}_{4} \omega^{2}\right)^{2}} \\
& \ldots \cdots \cdots \cdots \cdots \cdots \cdots \cdots \cdots \cdots \cdots \cdots \cdots \cdots \\
& C_{c}(\omega)=\frac{\left(\mathrm{b}_{1}+\mathrm{b}_{3} \omega^{2}\right)^{2}+\omega^{2}\left(\mathrm{~b}_{2}+\mathrm{b}_{4} \omega^{2}\right)^{2}}{\left(1+\mathrm{a}_{2} \omega^{2}+\mathrm{a}_{4} \omega^{4}\right)\left(\mathrm{b}_{1}+\mathrm{b}_{3} \omega^{2}\right)-\omega^{2}\left(\mathrm{a}_{1}+\mathrm{a}_{3} \omega^{2}\right)\left(\mathrm{b}_{2}+\mathrm{b}_{4} \omega^{2}\right)}
\end{aligned}
$$

である。Fig. 5 に $R_{c}(\omega)$ と $C_{c}(\omega)$ の計算結果を示す。抵抗 $R_{c}(\omega)$ は低周波数では高く, 高周波数では減少し 1 段目の内 部抵抗 $R_{\mathrm{c} 1}$ へ収束する。静電容量 $C_{c}(\omega)$ は, 低周波数では 定格静電容量值を示すが, 高周波になると減少し $C_{\mathrm{c} 1}$ へと収 束する。内部抵抗による電圧降下に加えて, この様な高周 波域での静電容量の低下により, 短時間充放電時の EDLC 電圧の変動量は, 定格静電容量で考慮した時よりも増加す る可能性があることがわかる。

\section{3. 実験装置}

Fig. 6 に実験システム構成を示す。駆動するモー夕は永 久磁石同期モー夕 (PMSM) を使用する。モー夕仕様を Table 2 に示す。また負荷としてロータイナーシャの 10.3 倍 の負荷イナーシャを取り付けた。

制御はDSP㧍よびFPGAを備えた制御ユニットで行った。 Fig. 7 に制御ブロック図を示す。制御ブロックは Fig. 7(a)

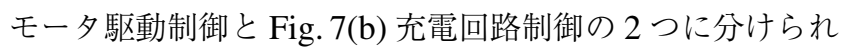
る。モータ駆動制御は電流制御ループをマイナーループと して持つ速度制御で構成され, 次の速度パターン「定格卜 ルクの 200\%で $3000 \mathrm{rpm}$ 一加速, 定速運転, 200\%トルク で減速停止」に追従するように制御を行う。 $i_{\mathrm{u}}$ と $i_{\mathrm{v}}, i_{\mathrm{w}}$ は モータ 3 相フィードバック電流, $i_{\mathrm{d}}$ と $i_{\mathrm{q}}$ は 3 相フィード バック電流を $\mathrm{dq}$ 座標系に変換した $\mathrm{d}$ 軸掞よび $\mathrm{q}$ 軸フィー ドバック電流， $\theta$ と $N$ はぞれぞれモー夕の回転角と速度で ある。電流ループ出力はキャリア比較 PWM によりゲート 信号に変換されインバータゲート回路へ出力される。一方, 充電回路制御はインダクタ L を流れる電流 $i_{\mathrm{L}}$ の電流制御 ループを持つ。電流指令值は充電モードにより異なる。電 源充電モード時は一定値である $i_{\mathrm{LC}}^{*}$ を与える。また回生充

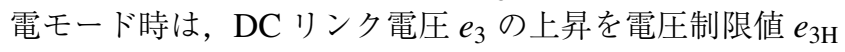
に抑制するため電圧制御を行う。さらに，応答性を高める ため，(2)，(3) 式によって得られる $i_{\mathrm{L}}$ の推定結果をフィー ドフォワードとして加算した $i_{\mathrm{Lr}}^{*}$ を電流制御ループへ出力 


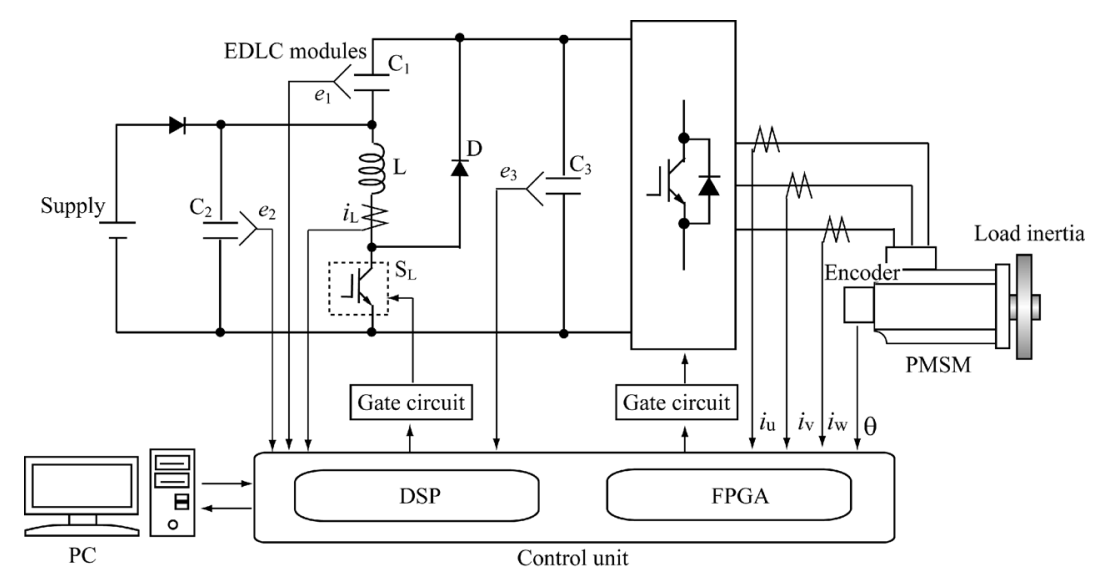

Fig. 6. Experimental system.

Table 2. Motor specifications in experiments.

\begin{tabular}{c|c}
\hline Rated power & $400 \mathrm{~W}$ \\
\hline Rated speed & $3000 \mathrm{rpm}$ \\
\hline Rated torque & $1.27 \mathrm{Nm}$ \\
\hline Rated currents & $5.6 \mathrm{Arms}$ \\
\hline Rotor inertia & $0.34 \times 10^{-4} \mathrm{kgm}^{2}$ \\
\hline
\end{tabular}

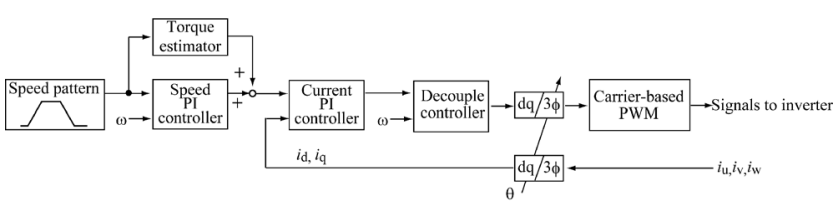

(a) Motor drive control

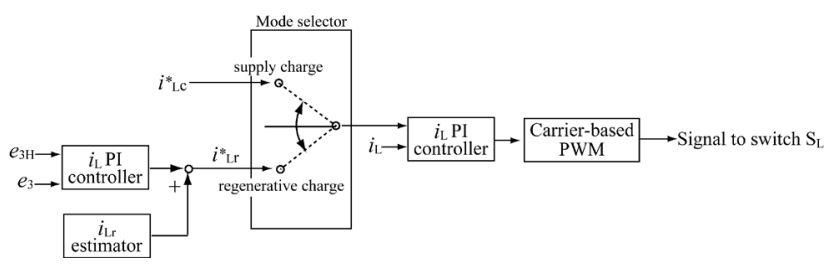

(b) EDLC charge control

Fig. 7. Control block diagrams.

する。制御出力はキャリア比較 PWM を介してチョッパス イッチ $\mathrm{S}_{\mathrm{L}}$ のゲート回路へ出力される。Fig. 8 に電流指令 $4 \mathrm{~A}$ とした時の電源充電モード時の波形を示す。電力ピー クを抑制するという本提案ドライバの一つの目的から, 電 流指令は最悪でも入力電力が加速時のピークを超えない範 囲で設定する必要がある。さらにパワーデバイスへの負荷 を考えると定格電力以下のできるだけ低い值を，それに伴 う充電時間の増加を考慮しながら設定する必要がある。

電源電圧は DC60 V とし, インバータ入力電圧を倍電圧す るため, あらかじめ電源充電モードでEDLCを約 $60 \mathrm{~V}$ に充 電している。このような電圧条件で実験を行ったのは, 駆動 するモー夕の定格電圧が AC100 Vであるためであり, 実際 に本提案ドライバを運用する際は, AC100 V や AC200 V と いった商用電源を整流平滑化した電圧に対しての昇圧が考え られる。 $C_{1}$ は EDLC モジュールを 6段直列接続した。その

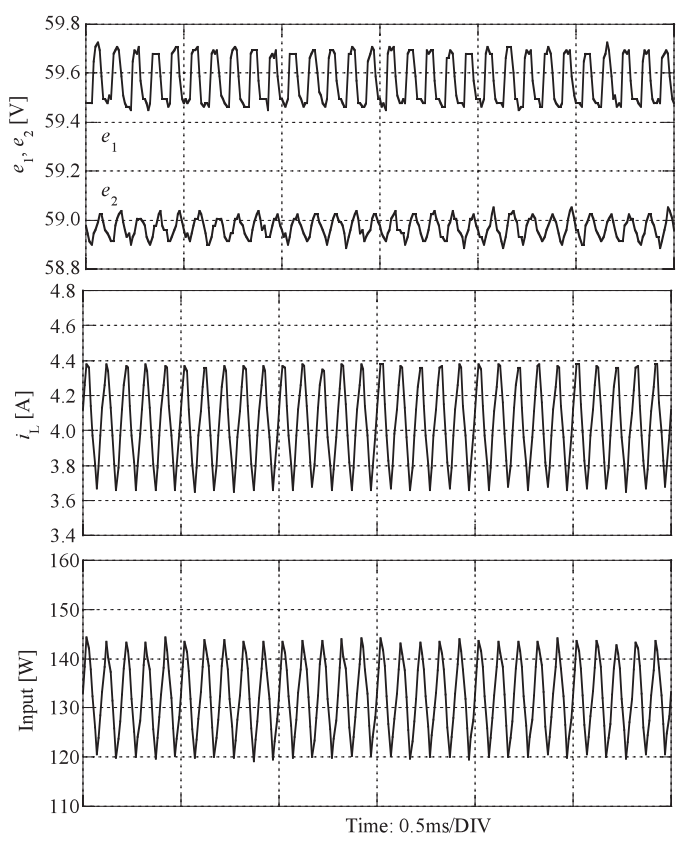

Fig. 8. Waveforms in supply charge mode.

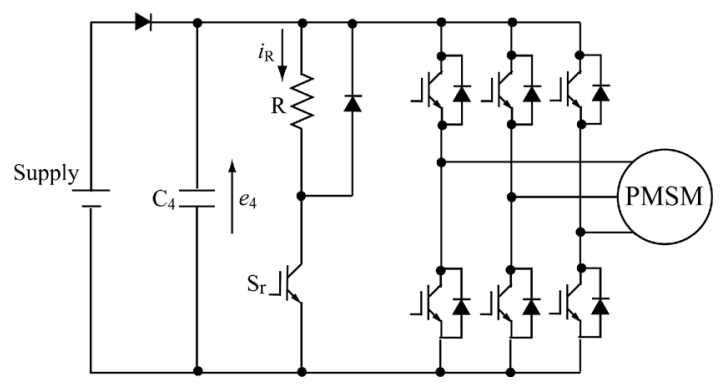

Fig. 9. Conventional motor driver.

他素子の定数は $C_{2}=0.94 \mathrm{mF}, C_{3}=0.22 \mathrm{mF}, L=4.53 \mathrm{mH}$ (等価抵抗 $0.4 \Omega$ ) である。また Fig. 9 に示す従来ドライバ においても電源電圧 $\mathrm{DC} 120 \mathrm{~V}$, 回生抵抗 $R=16.0 \Omega, C_{4}=$ $1.16 \mathrm{mF}$ とし, その他同じ条件で比較実験を行った。また 回生時の電圧上昇に対する制限電圧 $e_{3 \mathrm{H}}$ は提案ドライバ. 従来ドライバともに $130 \mathrm{~V}$ に設定した。なお, 従来ドライ バでは， $e_{3}$ が $e_{3 \mathrm{H}}$ を超えた時スイッチ $\mathrm{S}_{\mathrm{r}}$ を $\mathrm{ON}$ する方法 


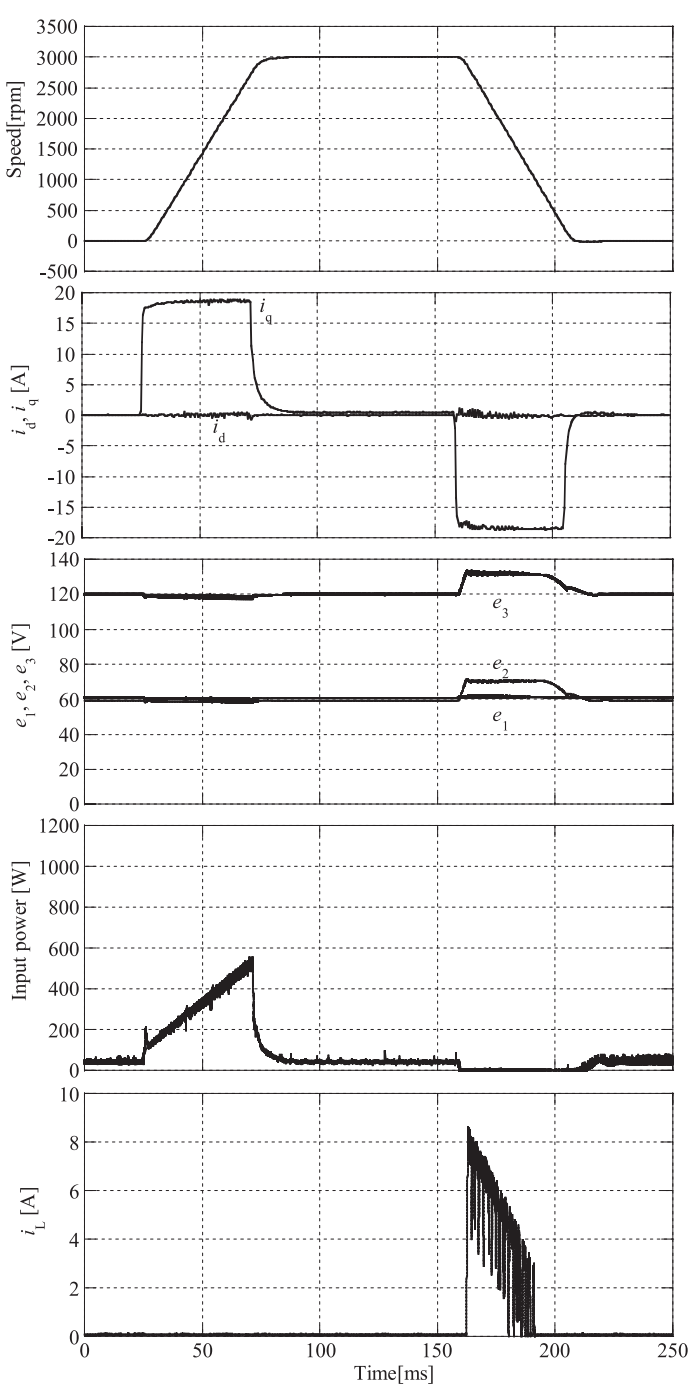

Fig. 10. Experimental results of proposed boost driver.

により，電圧上昇抑制制御を行った。このとき回生抵抗 $\mathrm{R}$ に流れる電流を $i_{\mathrm{R}}$ とする。

\section{4. 実験結果}

Fig. 10 と Fig. 11 にそれぞれ提案ドライバと従来ドライ バによる実験結果を示す。図はそれぞれ上から速度， $\mathrm{dq}$ 軸 フィードバック電流, DC 電圧, 入力電力, チョッパ電流/ 回生抵抗電流である。提案ドライバの結果から，加速時に EDLC 電圧 $e_{1}$ の低下はほとんど見られず $e_{3}$ は $120 \mathrm{~V}$ を保 持できており良好な昇圧性能が得られていることがわかる。 そのため, 高速時にも従来ドライバと同様に $i_{\mathrm{q}}$ を十分出力 できている。また，速度に関しても良好な制御波形を示し ており, 提案ドライバの駆動性能は劣化していないことが分 かる。一方, 入力電力ピークは従来ドライバでは約 $1200 \mathrm{~W}$ に達しているが，提案ドライバでは約 $600 \mathrm{~W}$ である。(2) 式に従って約半分になって抢り, 効果的に入力電力ピーク 低減を行えている。なお，停止時や定速度運転時に発生し ている入力電力は，主にインバー夕回路のスナバでの損失 分である。提案ドライバのその損失量は従来ドライバと等

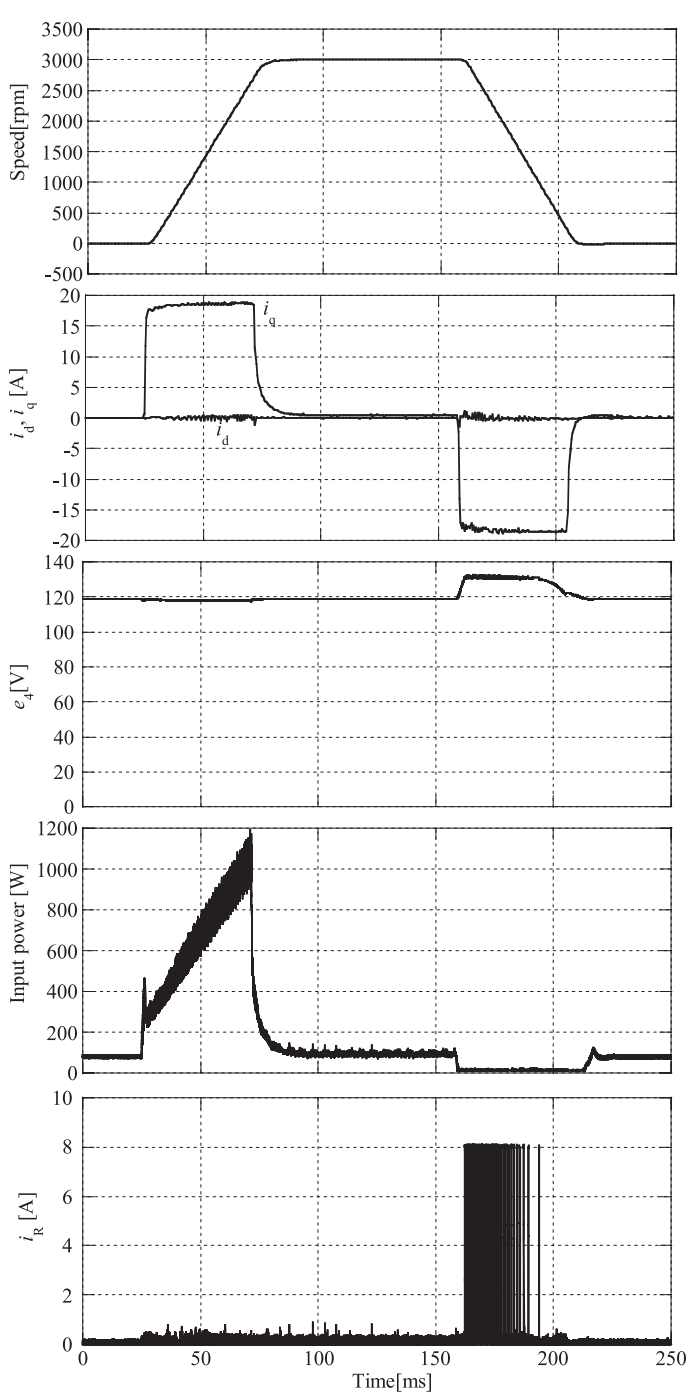

Fig. 11. Experimental results of conventional driver.

しいが，入力電力は従来ドライバの約半分である。この入 力電力の低下の理由も, 加速時と同様に, EDLC が損失の 半分を負担しているためである。ところで，減速時には回 生動作により電圧 $e_{3}$ が上昇しているが， $130 \mathrm{~V}$ に達したと ころで充電回路が働きチョッパ電流 $i_{\mathrm{L}}$ が流れている。この ようにエネルギーをEDLC に貯蔵することにより，電圧上 昇を $130 \mathrm{~V}$ 付近で効果的に抑制できている。対照的に従来 回路では電圧上昇の抑制のため, 電流 $i_{\mathrm{R}}$ が回生抵抗を流れ る。これにより $8.09 \mathrm{~J}$ のエネルギーが消費されており，提 案ドライバに扔ける回生エネルギーの EDCL 貯蔵の有効性 が確認された。なお, Fig. 11 に打ける $i_{\mathrm{R}}$ は, 回生時以外に もわずかな電流が流れているようにみえるが，実際は計測 器が拾ったノイズであり，上記消費エネルギーには考慮し ていない。

\section{5. シミュレーション結果}

Fig. 12 に，Fig. 3 に示した EDLC モデルを用いて，実験 と同条件で行ったシミュレーション結果を示す。なお，シ ミュレーションはPSIM (Powersim Inc.) にて実施した。ま 


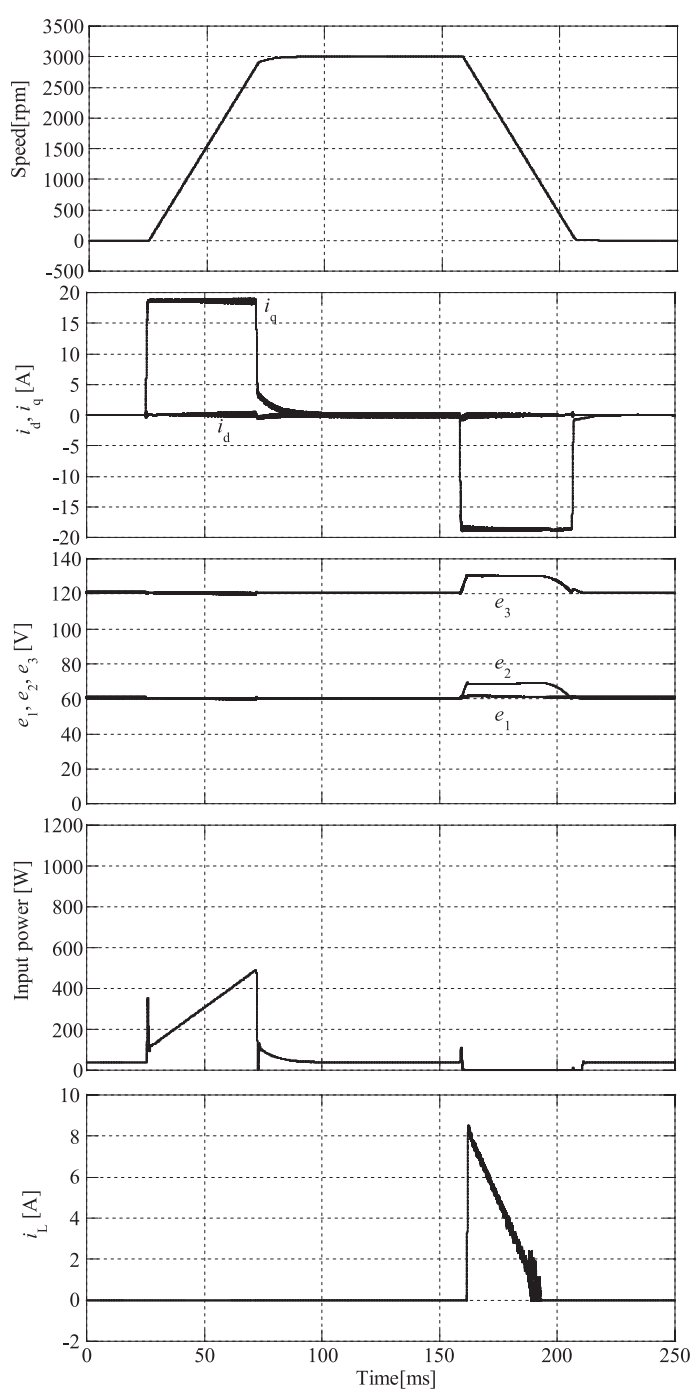

Fig. 12. Simulation results of proposed boost driver.

た Fig. 13 にレンジを拡大した EDLC 電圧を示し，実験結 果と比較している。これらの結果からシミュレーション結 果は，実駼結果とよく一致して打り整合性があることを確 認できる。また，シミュレーション結果内の $e_{1 \mathrm{f}}$ は EDLC モデル内の 1 段目の内部抵抗の影響を除いた電圧 $\left(\mathrm{C}_{\mathrm{c} 1}\right.$ 端

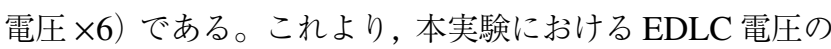
変動は充電電圧の変動 $\left(0.1 \mathrm{~V}\right.$ 未満) より, 内部抵抗 $\mathrm{R}_{\mathrm{c} 1}$ に 起因する変動（2.5V 程度）の方が大きいことが分かるが, いずれにしても電圧変動はわずかである。次に $0 \mathrm{~ms}$ （駆動 前), $150 \mathrm{~ms}$ (加速後), $250 \mathrm{~ms}$ (減速後) 時の EDLC の短時 間平均電圧のシミュレーションと実験の比較結果を Fig. 14 に示す。加えて，EDLC モデルとしてよく用いられている $\mathrm{RC}$ 直列回路モデルによる結果も示す。なお, $\mathrm{RC}$ 直列回路 モデルでは 1 モジュールあたりの静電容量をそれぞれ $116 \mathrm{~F}$ (定格值) と $7.00 \mathrm{~F}$ （EDLC モデル 1 段目）とし，内部抵抗 を共に $0.0171 \Omega$ とした $2 つ の$ 条件で行った。図より 4 段 時定数回路モデルを用いたシミュレーション結果が実験值 と最も近くなっている。また $\mathrm{RC}$ 直列回路モデルにて $C=$ $7.00 \mathrm{~F}$ とした時よりも $C=116 \mathrm{~F}$ の時の方が実験結果に近

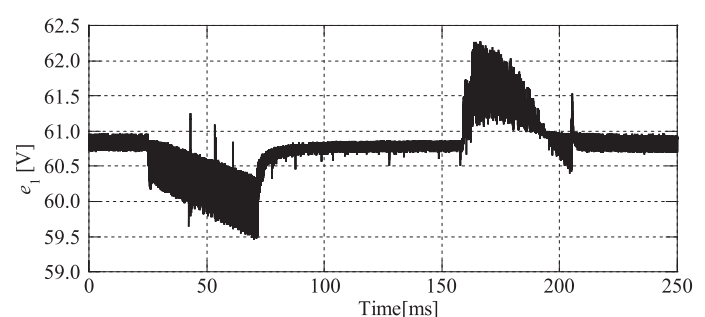

(a) Experimental result

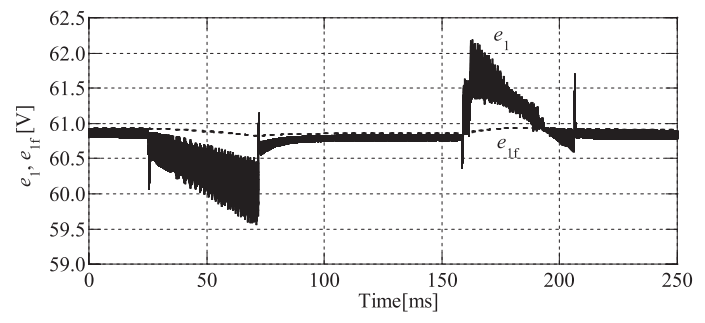

(b) Simulation results

Fig. 13. EDLC voltages.

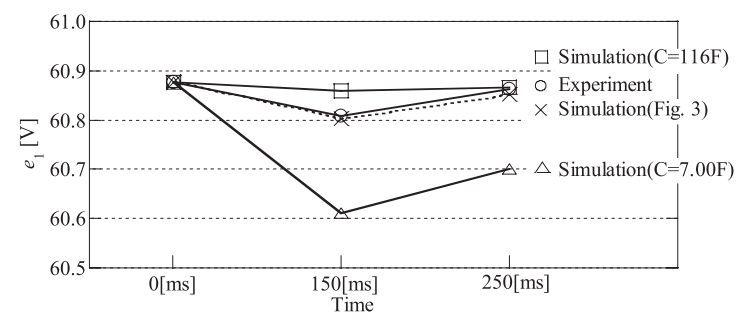

Fig. 14. Comparison between EDLC voltages.

く，短時間充放電時においても見かけ上の静電容量は定格 值と比べ大きく低下しないことが分かる。

6. まとめ

本論文では先に提案した EDLC を用いた昇圧形ドライ バについてモー夕加減速運転実験を行い，良好な昇圧性能 と電力ピーク低減, 回生エネルギー貯蔵・有効利用の 3 つ の特長に関して有効性を確認し, さらに駆動特性の劣化が ないことを確認した。また，EDLC モデルを用いてシミュ レーションを行い実験結果との整合性を実証した。さらに EDLC の静電容量の周波数依存特性は運転中の EDLC 充電 電圧変動に影響を及ぼすが，その変動量はわずかであるこ とをシミュレーションにより確認した。

以上, 従来ドライバと比較したとき, 提案ドライバのメ リットは

・電源設備容量低減によるコスト削減および体積削減

- 昇圧によるモー夕駆動応答性の向上と高効率化

- 回生エネルギーの有効利用による効率の向上と回生抵 抗設置体積の削減

であり，これに対しデメリットとしては

・比較的高価な EDLC 使用によるコスト増

・EDLC と充電回路インダクタの設置体積の増加

- EDLC の内部抵抗による損失増加

が挙げられる。これらはサーボシステムの使用状況（出力 
容量, 負荷, 運転パターン) やドライバ内の回路定数やス ペック（電解コンデンサ容量や定格電圧，回生抵抗值やそ の容量, 定格電流值) に大きく依存するため, 一概に比較・ 評価することは難しい。一方，条件次第では，実用的に使 用できる可能性は十分あると思われる。

ところで EDLC の電圧は加速時には低下するが，減速時 には回生電流により充電され，電圧はわずかに増加する。 しかし, 連続した加減速運転や長時間の定速運転に対して は，低下量の方が大きく EDLC の電圧低下は避けられない。 そのため長期的な運転時には，モー夕停止や定速運転中に 充電回路により EDLC 充電行うことが想定される。これら EDLC 充電に対する効果的な方法は，実用化に向けての今 後の課題として挙げられる。

(平成 21 年 3 月 20 日受付，平成 21 年 6 月 30 日再受付)

\section{文献}

(1) H. Matsumoto: "Proposal of Boost Motor Driver with Electric Double Layer Capacitor", T. IEE Japan, Vol.129, No.2, pp.230-231 (2009-2) (in Japanese) 松本洋和：「電気二重層キャパシタを用いた昇圧形モータドライバ の提案」, 電学論 D, 129, 2, pp.230-231 (2009-2)

(2) 岡村廸夫：「電気二重層キャパシタと蓄電システム第 3 版」, 日刊工 業新聞 (2005)

(3) K. Yamamoto, K. Shinohara, and S. Furukawa: "PWM Inverter with Boost Converter for Motoring Operation and Buck Converter for Regenerating Operation", National Convention Record IEE Japan, 4-063, pp.96-97 (2006) (in Japanese)

山本吉郎・篠原勝次・古川真也：「力行用昇圧チョッパと回生用降 圧チョッパを付加した PWM インバータ」, 平 18 電学全大, 4-063, pp.96-97 (2006)

(4) T. Kishimoto, R. Miyagawa, K. Matsuse, T. Yamada, T. Ashikaga, and K. Oyamada: "Inverter System of Harmonics Suppression with Electrical Double Layer Capacitor", National Convention Record IEE Japan, 4-159, pp.260-261 (2002) (in Japanese)

岸本岳志 ·宮川良平 · 松瀬貢規 - 山田哲夫 · 足利 正 - 小山田健四 朗：「大容量電気二重層キャパシタを用いる高調波抑制型インバー 夕装置」, 平 14 電学全大, 4-159, pp.260-261 (2002)
(5) S. Hase, T. Konishi, A. Okui, Y. Nakamichi, H. Nara, and T. Uemura: "Application of Electric Double-layer Capacitors for Energy Storage on Electric Railway", T. IEE Japan, Vol.123, No.5, pp.517-524 (2003-5) (in Japanese) 長谷伸一・小西武史・奥井明伸・中道好信 - 奈良秀隆・上村 正 : 「電気二重層キャパシタを用いた電力貯蔵装置の電気鉄道への適用 に関する基礎的検討」, 電学論 D, 123, 5, pp.517-524 (2003-5)

(6) Y. Taguchi, M. Ogasa, H. Hata, H. Iijima, S. Otsuyama, and T. Funaki: "A Simple Construction of Series-Input Energy Storage Device Connected with Inverter", The papers of Technical Meeting on Transportation and Electric Railway, IEE Japan, TER-06-74, pp.27-32 (2006) (in Japanese) 田口義晃·小笠正道・秦広・飯島宏康 - 大津山澄明 - 舟木 剛： 「インバータ入力直列蓄電装置のシンプルな構成方法」, 電学研資, TER-06-74, pp.27-32 (2006)

(7) T. Funaki and T. Hikihara: "A Study on Modeling of EDLC-Frequency characteristics and voltage dependency of capacitance-", The Paper of Technical Meeting on Vehicle Technology, IEE Japan, VT-07-19, pp.53-58 (2007) (in Japanese)

舟木 剛・引原隆士：「電気二重層コンデンサのモデリングに関す る一検討一静電容量の周波数特性·充電電圧依存性一」, 電学研資, VT-07-19, pp.53-58 (2007)

(8) D. Seki, M. Tooyama, S. Yamashiro, M. Sasaki, and S. Araki: "A Study on Electric Characteristics of EDLC (5)", National Convention Record IEE Japan, 7-127, pp.181-182 (2002) (in Japanese)

山田 哲·仲村宏一・山城 迪·佐々木正和 - 荒木修一：「高出力密 度型電気二重層キャパシタの電気特性に関する考察 (5)」, 平 14 電学 全大, 7-128, pp.181-182 (2002)

(9) T. Uchida, E. Takahara, and J. Yamada: "Research of Electric Double Layer Capacitors for the Electric Vehicle with Fuel Cell Simulator", National Convention Record IEE Japan, 4-201, pp.318-319 (2006) (in Japanese) 内田寿幸・高原英明・山田 淳:「燃料電池模擬回路電気自動車による 電気二重層キャパシタ特性の検討」, 平 18 電学全大, 4-201, pp.318-319 (2006)

松 本 洋 和 (正員) 1977 年 11 月 18 日生。 2004 年 3 月九

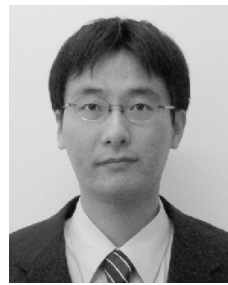
州大学大学院システム情報科学府博士後期課程修 了。同 4 月九州大学 COE 研究員。2005 年 4 月 三菱電機 (株) 入社。2008 年 4 月福岡大学工学 部電気工学科助教。博士 (工学)。現在, パワー エレクトロニクス, 電気機器制御, 磁界解析の研 究に従事。 